\title{
SPEECH-EVOKED CORTICAL POTENTIALS IN NORMAL- HEARING CHILDREN AND ADULTS USING THREE PHONEMES
}

\author{
Prawin Kumar, Himanshu Kumar Sanju, Vaishnavi Bohra, Astha Khanna
}

Department of Audiology, All India Institute of Speech and Hearing, Mysore, India

Corresponding author: Himanshu Kumar Sanju, Department of Audiology, All India Institute of Speech and Hearing, Mysore, India, e-mail: himanshusanjuaiish@gmail.com

\begin{abstract}
Background: The neural representation of different speech stimuli (phonemes) can be measured at the cortex using electrophysiological techniques, a procedure called speech-evoked cortical potentials. Each phoneme produces cortical potentials with different temporal and spectral properties. Latency and amplitude measures reflect changes in the way different phonemes are neurally represented, so these measures are expected to change with maturation of the system, that is with age. The aim of the present study to investigate whether there were differences in latency and amplitude between children and adults in response to the three phonemes $/ \mathrm{m} /, \mathrm{g} /$, and $/ \mathrm{t} /$.
\end{abstract}

Material and methods: Exactly 10 normal-hearing children of age 5-7 years and 10 normal-hearing adults of age 17-24 years were recruited. Speech-evoked cortical potential were recorded using the HEARLab (v.1.0) auditory evoked potential system. Non-parametric statistics were used to compare both groups.

Results: Mann-Whitney U-tests shows statistically significant differences between children and adults for both the latency and amplitude of wave P1 and N1 at the 0.05 level. At the same time, there were no significant differences between $/ \mathrm{m} /, / \mathrm{g} /$, and /t/ for children and adults at the same level when a Kruskal-Wallis test was applied.

Conclusions: The present study shows there are differences between children and adults in terms of the latency and amplitude of their cortical potential responses, but the particular phoneme used does not appear to make a difference.

Keywords: adults $\bullet$ children $\bullet$ auditory cortex $\bullet$ speech $\bullet$ phonemes

\section{MEDICIÓN DE LOS POTENCIALES CORTICALES EVOCADOS POR EL HABLA EN NIÑOS Y ADULTOS CON LA AUDICIÓN CORRECTA, CON APLICACIÓN DE DIFERENTES ESTÍMULOS DEL HABLA}

\section{Resumen}

Introducción: Una forma natural de evaluación de distintos estímulos del habla (fonemas) son los métodos electrofisiológicos, llamados potenciales corticales, evocados por el habla. Cada fonema genera potenciales corticales de distintas propiedades temporales y espectrales. Las mediciones de latencia y amplitud reflejan los cambios en una presentación natural de distintos fonemas; por este motivo se espera que estas mediciones vayan a cambiar con la maduración del sistema con la edad. El objetivo del estudio es comprobar si existen diferencias en la latencia y amplitud entre niños y adultos en respuesta a tres fonemas $/ \mathrm{m} /, \mathrm{g} / \mathrm{y} / \mathrm{t} /$.

Materiales y métodos: Se han elegido exactamente 10 niños con audición normal, en la edad de 5 a 7 años y 10 adultos de 17 a 24 años. Los potenciales corticales evocados por el habla fueron controlados a través del sistema de potenciales auditivos evocados HEARLab (v1.0). Se ha hecho la comparación entre grupos utilizando estadística no paramétrica.

Resultados: La prueba U de Mann- Whitney muestra diferencias estadísticamente relevantes entre los niños y los adultos, con respecto tanto a la latencia y la amplitud de las ondas P1 y N1 en el nivel de 0,005. Al mismo tiempo, no se han registrado diferencias significativas entre los fonemas $/ \mathrm{m} / \mathrm{g} / \mathrm{g} / \mathrm{y} / \mathrm{t} /$ - el nivel ha sido igual tanto para los niños, como y para los adultos, con la aplicación de la prueba de Kruskal-Wallis.

Conclusiones: Este estudio demuestra la existencia de diferencias entre niños y adultos en cuanto a la latencia y la amplitud en respuestas de los potenciales corticales, sin embargo, el uso del fonema particular no tiene importancia.

Palabras clave: adultos $\bullet$ niños $\bullet$ corteza auditiva $\bullet$ habla $\bullet$ fonemas 


\section{ИЗМЕРЕНИЯ КОРКОВЫХ ПОТЕНЦИАЛОВ, ВЫЗВАННЫХ РЕЧЬЮ, У ДЕТЕЙ И ВЗРОСЛЫХ С НОРМАЛЬНЫМ СЛУХОМ С ИСПОЛЬЗОВАНИЕМ РАЗНЫХ РЕЧЕВЫХ ИМПУЛЬСОВ}

\section{Изложение}

Введение: Естественной формой оценки разных речевых импульсов (фонем) являются электрофизиологические методы, называемые корковыми потенциалами, вызванными речью. Каждая фонема производит корковые потенциалы, имеющие разные временные и спектральные свойства. Измерения латенции и амплитуды отображают изменения в естественном представлении разных фонем, поэтому ожидается, что эти измерения будут изменяться вместе с возрастным созреванием системы. Цель этого исследования - проверить, была ли разница латенции и амплитуды между детьми и взрослыми в ответ на три фонемы /м/б /г/и /т/.

Материал и методы: Были выбраны ровным счетом 10 детей с нормальным слухом в возрасте от 5 до 7 лет и 10 взрослых в возрасте от 17 до 24 лет. Корковые потенциалы, вызванные речью, были контролированы с помощью системы слуховых вызванных потенциалов HEARLab (v1.0). Группы сравнены с использованием непараметрических статистик.

Результаты: U-критерий Манна-Уитни показывает статистически значимую разницу между детьми и взрослыми как по отношению к латенции, так и амплитуды волны P1 и N1 на уровне 0,005. В то же время не было существенной разницы между /м/, /г/ и /т/ для детей и взрослых на том самом уровне с использованием критерия Краскела-Уоллиса.

Итоги: Настоящие исследования показывают, что существует разница между детьми и взрослыми в области латенции и амплитуды в ответах корковых потенциалов, но использование конкретной фонемы не имеет значения.

Ключевые слова: взрослые • дети • слуховая кора • речь • фонемы

\section{POMIARY POTENCJAŁÓW KOROWYCH WYWOŁANYCH MOWĄ U DZIECI I DOROSŁYCH Z NORMALNYM SŁUCHEM PRZY UŻYCIU RÓŻNYCH BODŹCÓW MOWY}

\section{Streszczenie}

Wprowadzenie: Naturalną formą oceny różnych bodźców mowy (fonemów) są metody elektrofizjologiczne, zwane potencjałami korowymi wywołanymi mową. Każdy fonem wytwarza potencjały korowe o różnorodnych właściwościach czasowych i spektralnych. Pomiary latencji i amplitudy odzwierciedlają zmiany w naturalnym przedstawieniu różnych fonemów, dlatego oczekuje się, że pomiary te będą się zmieniały wraz z dojrzewaniem systemu z wiekiem. Celem jest zbadanie czy istniały różnice latencji i amplitudy pomiędzy dziećmi i dorosłymi w odpowiedzi na trzy fonemy $/ \mathrm{m} /, \mathrm{g} / \mathrm{i} / \mathrm{t} /$.

Materiał i metody: Wybrano dokładnie 10 dzieci z normalnym słuchem w wieku 5-7 lat i 10 dorosłych w wieku 17-24 lat. Potencjały korowe wywołane mową były monitorowane za pomocą systemu słuchowych potencjałów wywołanych HEARLab (v1.0). Grupy porównano używając statystyki nieparametryczne.

Wyniki: Test U Manna-Whitneya pokazuje statystycznie istotne różnice pomiędzy dziećmi i dorosłymi zarówno w odniesieniu do latencji jaki i amplitudy fali P1 i N1 na poziomie 0,005. Jednocześnie nie było istotnych różnic pomiędzy /m/, /g/ i /t/ dla dzieci i dorosłych na tym samym poziomie przy użyciu testu Kruskala-Wallisa.

Wnioski: Niniejsze badania pokazują, że są różnice pomiędzy dziećmi i dorosłymi w zakresie latencji i amplitudy w odpowiedziach potencjałów korowych, ale użycie konkretnego fonemu nie ma znaczenia.

Słowa kluczowe: dorośli • dzieci • kora słuchowa • mowa • fonemy

\section{Background}

Cortical auditory evoked potentials (CAEPs) are non-invasive measures of acoustically evoked potentials, components of the electroencephalogram (EEG) which can reflect longterm changes in auditory cortical maturation. CAEPs are long-latency evoked potentials which can be used to assess integrity of the central auditory system. CAEPs reflect 
maturation of the human brain through changes in their latency, amplitude, and morphology [1]. CAEPs are composed of four waves whose latency ranges from 80 to 300 ms: a positive peak (P1) at about $50 \mathrm{~ms}$, a large negative peak (N1) at about 80 to $100 \mathrm{~ms}$, a second positive peak (P2) at about 180 to $200 \mathrm{~ms}$, and a negative peak (N2) at 220-270 ms [2]. CAEPs can be used as an objective method to estimate hearing thresholds [3]. The morphology of the CAEP waveform depends on several factors, such as age [4], attention [5], sleep state [6], presentation parameter [7], and electrode recording position $[8,9]$. The latency of the CAEP differs depending upon the age of the individual. The positive peak ranges from about $250 \mathrm{~ms}$ (birth) to $100 \mathrm{~ms}$ (childhood), while the low-amplitude negative peak ranges from 450-600 ms (birth) to $200 \mathrm{~ms}$ (childhood). The latency decreases with age as the auditory system develops [10]. From the 8th year of life, N1 starts separating from $\mathrm{P} 1$ and $\mathrm{P} 2$, and this continues up to adulthood, when CAEPs finally show distinct P1, N1, P2, and N2 [9].

CAEPs are generated by multiple temporally overlapping subcortical and cortical sources $[11,12]$. These components are automatically elicited and the subject is not required to perform any task - they are simply asked to remain alert. Since they are not affected by behavioural or performance-related demands, these evoked responses provide a reliable objective measure of cortical auditory function in both children and adults. Development of the peripheral auditory system (ear and auditory brainstem) is complete in early childhood; in contrast, central auditory pathways of the human brain exhibit progressive anatomical and physiological changes through early childhood [13]. This maturation is likely to have an impact on speech and oral language skills, which are primarily acquired through the auditory modality.

Kraus et al. (1993) found that CAEPs can also be elicited by using speech stimuli, which can help in quantifying performance of the central auditory system [14]. Later, Carter et al. (2013) [15] showed that the CAEP is a sensitive tool for evaluating the audibility of speech sounds in children who have hearing impairments. Speech-evoked CAEPs provide an objective measure of central auditory processing [16], and they are commonly used to observe how speech sounds are neurally represented. The $\mathrm{P} 1-\mathrm{N} 1-\mathrm{P} 2$ complex shows temporal and spectral cues that depend on age, so that changes in the latency and amplitude of the complex and probably reflect maturation in the way that different speech stimuli are neurally represented. According to a study by Trembley et al. (2003) [17], naturally produced speech tokens, having different acoustic cues, evoke distinct neural response patterns. Kaushlendra et al. [18] showed in 2011 that CAEPs may be used to objectively measure differences in neural encoding and perception of spectrally different speech sounds. A study in 2013 by Sharma et al. [19] using speech stimuli on 5 hearing impaired children with multiple disabilities showed that the P1 CAEP marker could be used to objectively evaluate the maturation of central auditory pathways, helping to determine the effectiveness of various intervention strategies. Elangovan and Andrew reported in 2011 that changes in morphology of the P1-N1P2 complex were related to acoustical changes in speech sounds; moreover they were independent of phonetic categorization of voicing cues across language groups [20].
Another study on CAEPs by Easwar et al. [21] on 16 adults suggested that incorporating naturally produced speech sounds is important to account for temporal and spectral variations and that they should be selected so as to optimise the characteristics of the CAEP. Easwar et al. [21] also reported good test-retest reliability of CAEP measures using speech as stimuli. Similarly, a study by Shafer and Waqner examined the maturation of CAEPs from 3 months of age to 8 years of age [22]. They reported that, for amplitude, only P1 showed a clear relationship with age, becoming more positive in a linear fashion. Almeqbe [23] studied 18 school-age children with normal hearing who were tested in two age-groups: younger (5-7 years) and older (8-12 years). They found that spectrally different speech sounds were encoded differently at the cortical level and evoked distinct CAEP response patterns. They also reported that CAEP latencies and amplitudes may provide objectively indicate that spectrally different speech sounds are encoded differently at the cortical level.

From the above literature, there seems to be a dearth of information on speech-evoked CAEPs, particularly in comparing different speech stimuli in children and adults with normal hearing. The aim of the present study was therefore to find out, using latency and amplitude measures of CAEPs, aspects of the way in which different speech stimuli $(/ \mathrm{m} /, / \mathrm{t} /$, and $/ \mathrm{g} /)$ are neurally represented in children and adults with normal hearing.

\section{Material and methods}

There were 20 participants with normal hearing selected for the study: 10 children recruited from a private primary school ( 5 males and 5 females aged 5 to 7 years), and 10 adults recruited from a private science college ( 5 males and 5 females aged 17 to 24 years). Informed written consent was taken from the adults and from the parents of all children. All participants had hearing sensitivity within normal limits ( $\leq 15 \mathrm{~dB} H \mathrm{HL})$ in both ears. They had normal middle ear function as indicated by immittance evaluation. Further, they had no history of otologic or neurologic problems, and they were well on the day of testing.

\section{Testing environment}

All behavioural and electrophysiological tests were carried out in a sound-treated room in which noise levels were within ANSI S3.1 (1991) guidelines. The rooms were well illuminated and comfortable.

\section{Instrumentation}

A calibrated two-channel clinical audiometer (Orbitor-922) was used for pure tone audiometry. A calibrated GSI-Tympstar immittance meter was used for tympanometry and reflexometry. A Biologic Navigator Pro EP (v.7.07) was used for ABR threshold estimation. A HEARLab (v.1.0) system was used for recording speech-evoked cortical potentials.

\section{Procedure}

Pure tone audiometry was done at octaves from 250 to $8000 \mathrm{~Hz}$ for air conduction and between 250 to $4000 \mathrm{~Hz}$ 
Table 1. Parameters for recording click-evoked ABRs and speech-evoked cortical potentials

\begin{tabular}{|c|c|c|}
\hline & Click-evoked ABR & Speech-evoked cortical potential \\
\hline Stimulus & Click (100 ㅆs duration) & /m/ (30 ms); /g/ (30 ms); /t/ (30 ms) \\
\hline Electrode placement & $\begin{array}{l}\text { Reference M1 } \\
\text { Active Fz } \\
\text { Ground M2 }\end{array}$ & $\begin{array}{l}\text { Reference M1/M2 } \\
\text { Active } \mathrm{Cz} \\
\text { Ground Fz }\end{array}$ \\
\hline Intensity & $80 \mathrm{~dB} n \mathrm{~nL}$ & $65 \mathrm{~dB}$ SPL \\
\hline Transducer & Insert earphones & Loudspeaker \\
\hline Transducer position & None & 0 degree azimuth \\
\hline Ear & Monaurally & Monaurally \\
\hline Polarity & Alternating & Alternating \\
\hline Filter setting & $100-3000 \mathrm{~Hz}$ & $1-30 \mathrm{~Hz}$ \\
\hline Repetition rate & $30.1 / \mathrm{sec}$ & $1.1 / \mathrm{sec}$ \\
\hline Total No. of sweeps & 2000 & 200 \\
\hline Impedance & $<5 \mathrm{k} \Omega$ & $<5 \mathrm{k} \Omega$ \\
\hline No. of channels & 1 & 1 \\
\hline Analysis time & $10 \mathrm{sec}$ & $500 \mathrm{~ms}$ \\
\hline
\end{tabular}

for bone conduction using the modified Hughson Westlake procedure. Immittance audiometry was carried out with a probe frequency of $226 \mathrm{~Hz}$. Ipsilateral and contralateral acoustic reflex thresholds was measured at 500, 1000, 2000, and $4000 \mathrm{~Hz}$. Click-evoked ABR was carried out to verify the normal hearing sensitivity of participants whenever required. For ABR recording, the subject was seated in a reclining chair. The skin surface at the two mastoids (M1, M2) and forehead (Fz) was cleaned with skin abrasive to obtain skin impedance of less than $5 \mathrm{k} \Omega$ for all electrodes. The electrodes were placed with the help of skin conduction paste and surgical plaster was used to secure them tightly in place. To minimise artifacts, participants were instructed to relax and refrain from extraneous body movements. Testing was done monaurally.

For speech-evoked cortical potential recording, the HEARLab system was used. The participant was seated at the test position with his/her head approximately $1 \mathrm{~m}$ from the loudspeaker positioned at $0^{\circ}$ azimuth. The participant was encouraged to sit quietly. Stimuli were presented at a fixed interstimulus interval of $1125 \mathrm{~ms}$ (onset to offset). Disposable self-adhesive button electrodes were used. HEARLab uses an automatic statistical detection procedure that does not require subjective interpretation from the operator. A system-generated $p$-value determines the presence or absence of a response. Testing was done using the default settings. Three speech stimuli $(/ \mathrm{m} /, / \mathrm{g} /$, and $/ \mathrm{t} /)$ at $65 \mathrm{~dB}$ SPL were used for recording CAEPs. Details of the protocols are given in Table 1.

\section{Speech stimuli}

The speech stimuli were $/ \mathrm{m} /$ (duration $30 \mathrm{~ms}$ ), /g/ (duration $21 \mathrm{~ms}$ ), and /t/ (duration $30 \mathrm{~ms}$ ) incorporated in
HEARLab system in identical form. The stimuli were extracted from a digital recording of uninterrupted dialogue spoken by a female with an average Australian accent at a sampling rate of $44.1 \mathrm{kHz}$. Very little vowel transition was included in the stimuli. An additional high-pass filter of $250 \mathrm{~Hz}$ was applied to /t/ to remove low-frequency noise. These three essentially vowel-free speech sounds $/ \mathrm{m} / \mathrm{g} / \mathrm{g} /$, and $/ \mathrm{t} / \mathrm{have}$ spectral emphasis in the low, mid, and highfrequency regions respectively.

\section{Statistical analysis}

The data were analysed using SPSS (v.17) for descriptive and non-parametric test analysis.

Because of the small sample size, non-parametric tests were used for statistical analysis for data collected from the two groups. A Mann-Whitney $U$-test was used to determine differences between children and adults for latency and amplitude measures of wave P1 and N1 at 0.05 levels. Similarly, a Kruskal-Wallis test was used to determine differences across speech stimuli for children and adults at 0.05 levels.

\section{Results}

\section{P1 latency and amplitude}

A Mann-Whitney $U$ test revealed that adults had significantly shorter latency compared to children $(U=61$, $p=0.000$, two-tailed). Similarly, Mann-Whitney U test also showed a significant difference between children and adult in terms of amplitude of wave P1 ( $U=261.5, p=0.00$, two-tailed). 


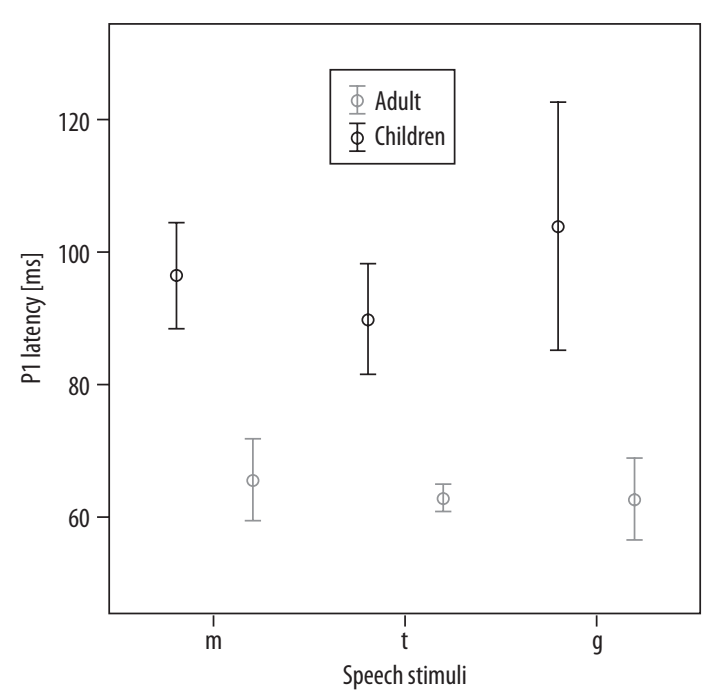

Figure 1. Latency of P1 in children and adults for three different stimuli

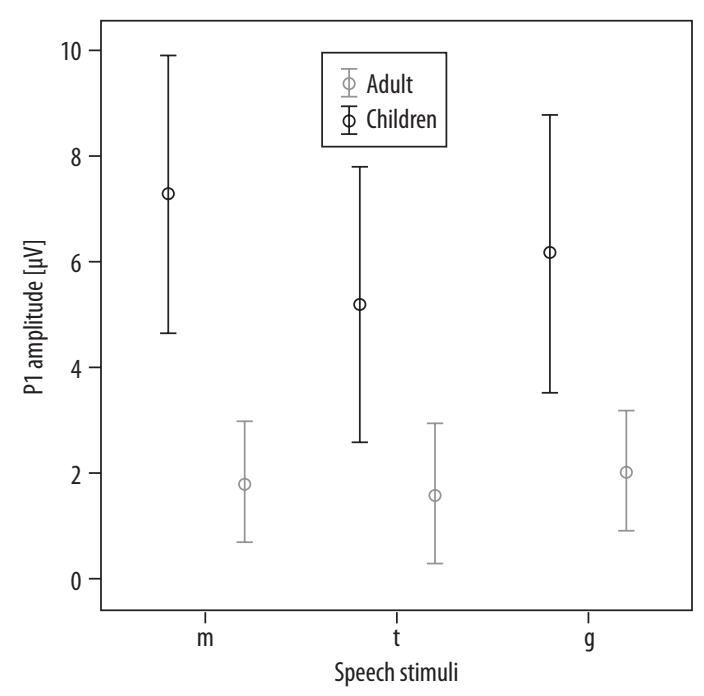

Figure 2. Amplitude of $P 1$ in children and adults for the three stimuli

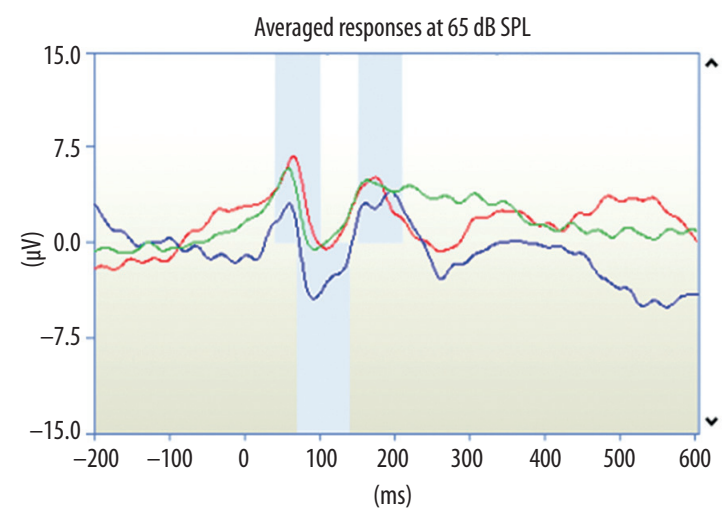

Figure 3. Average CAEP waveforms in adults showing P1, $\mathrm{N} 1$, and P2 (blue backgrounds) for the three stimuli. Key: red $=/ \mathrm{m} /$; green $=/ \mathrm{g} /$; blue $=/ \mathrm{t} /$.

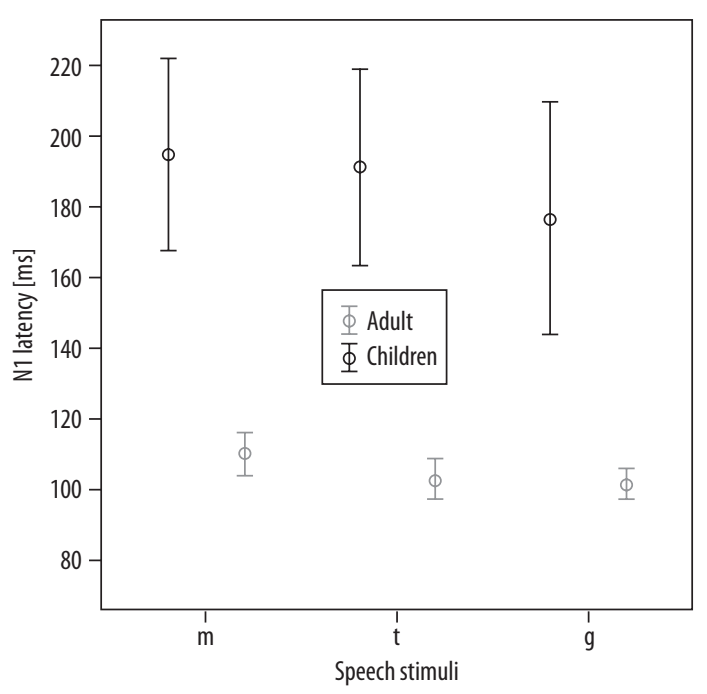

Figure 4. Latency of $\mathrm{N} 1$ in children and adults for the three different stimuli

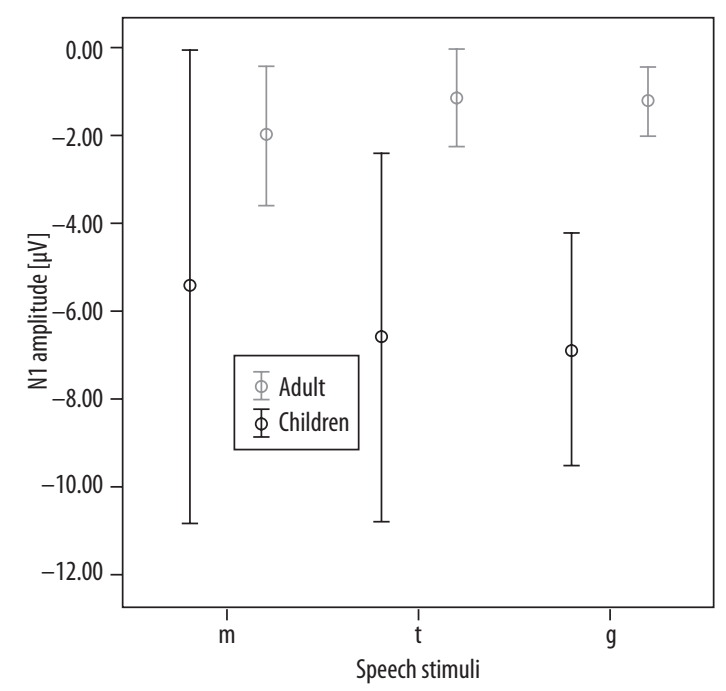

Figure 5. Amplitude of N1 in children and adults for the three stimuli

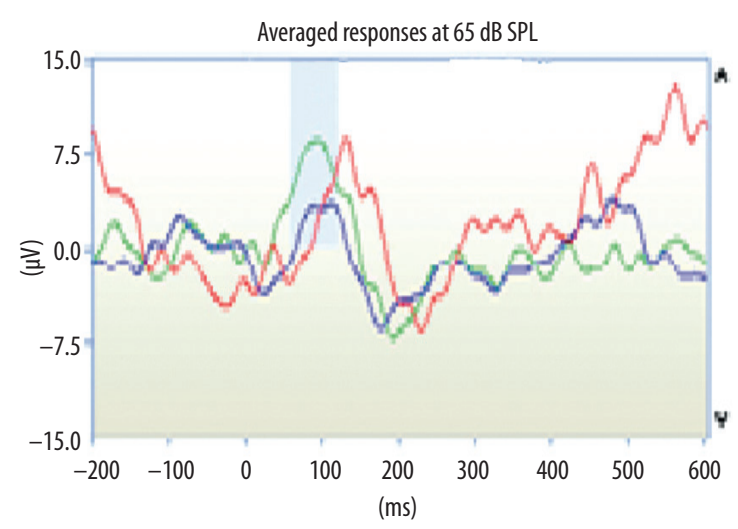

Figure 6. Average CAEP waveforms in children showing P1, N1, and P2 (blue backgrounds) for the three stimuli. Key: red=/m/; green=/g/; blue=/t/. 


\section{N1 latency and amplitude}

The Mann-Whitney $U$-test showed that adults had significantly shorter latency compared to children $(U=170$, $p=0.000$, two-tailed). Similarly, the Mann-Whitney $U$-test also revealed a significant difference between children and adults with $\mathrm{N} 1$ amplitude ( $U=408.5, p=0.000$, two-tailed).

Kruskal-Wallis tests were used to discern differences across different speech stimuli for children and adults at 0.05 levels.

\section{For children}

For P1, the Kruskal-Wallis test revealed that there was no significant difference across stimuli $(/ \mathrm{m} /, / \mathrm{g} /$, or $/ \mathrm{t} /)$ in terms of P1 latency $\left(\chi^{2}=0.485, \mathrm{df}=2, p>0.05\right)$ or P1 amplitude $\left(\chi^{2}=0.589, \mathrm{df}=2, p>0.05\right)$. Similarly, for $\mathrm{N} 1$, the Kruskal-Wallis test revealed that there was no significant difference across stimuli $(/ \mathrm{m} /, / \mathrm{g} /$, and $/ \mathrm{t} /)$ in terms of latency $\left(\chi^{2}=2.56, \mathrm{df}=2, p>0.05\right)$ or amplitude $\left(\chi^{2}=0.143\right.$, $\mathrm{df}=2, p>0.05)$.

\section{For adults}

For P1, the Kruskal-Wallis test showed that there was no significant difference across stimuli $(/ \mathrm{m} /, / \mathrm{g} /$, and $/ \mathrm{t} /)$ in terms of P1 latency $\left(\chi^{2}=0.356, \mathrm{df}=2, p>0.05\right)$ or in terms of P1 amplitude $\left(\chi^{2}=0.218, \mathrm{df}=2, p>0.05\right)$. Similarly, for $\mathrm{N} 1$, the Kruskal-Wallis test revealed that there was no significant difference across stimuli $(/ \mathrm{m} /, / \mathrm{g} /$, and $/ \mathrm{t} /)$ in terms of N1 latency $\left(\chi^{2}=5.145, \mathrm{df}=2, p>0.05\right)$ or in terms of $\mathrm{N} 1$ amplitude $\left(\chi^{2}=1.577, \mathrm{df}=2, p>0.05\right)$.

\section{Discussion}

The aim of the present study was to measure aspects of the neural representation of different speech stimuli $(/ \mathrm{m} /, / \mathrm{t} /$, and $/ \mathrm{g} /$ ) in children and adults with normal hearing. Robust P1, N1, and P2 responses were obtained for all participants in both groups. For the different speech sounds, there were statistically significant differences (at the 0.05 level) between children and adults for latency and amplitude measures of wave $\mathrm{P} 1$ and N1. This is probably because CAEPs reflect maturation of the human brain through changes in latency, amplitude, and morphology [1,24,25]. Similar to a 2013 study done by Cone and Whitaker [26],
CAEP component latencies in younger subjects were prolonged compared to adults. The present study did not show any significant differences across different speech stimuli for children or adults, a result supported by the 2012 study done by Dun and colleagues [27] on children. This is in contrast with Golding et al. [7] who reported in 2006 that the cortical responses evoked by a / $t$ / sound were significantly larger in amplitude and shorter in latency than for the other two sounds. A study on adults in 2011 by Munro et al. [28] using HEARLab also reported, for different speech stimuli, that the plosive speech contrasts / $t$ / and $/ \mathrm{g} /$ used to evoke CAEPs in their study did not reliably result in different CAEP waveforms. A similar study in 2007 by Garinis and Cone [29] also reported no significant difference in CAEP waveforms for /sa/ and /da/ in terms of either amplitude or latency. Thus distinguishing CAEP responses using different speech stimuli is not an appropriate method to objectively demonstrate that the brain has discriminated between these speech stimuli. The above results probably reflect a similar neural representation of different speech stimuli in children and adults.

\section{Conclusions}

The present study shows that there are differences, in terms of latency and amplitude measures, in CAEPs between children and adults, that is, there is a clear maturational change. However, the neural representations of different speech stimuli are shown to be similar in both children and adults with normal hearing. There is therefore a need for an alternative objective electrophysiological measure of speech discrimination in individuals. The outcomes from the present study can probably be helpful as a baseline while researchers prepare to test cortical potential measures in clinical populations such as individuals with hearing impairment.

\section{Acknowledgement}

We thank the Director, AIISH, Mysore, and Head of Department of Audiology, AIISH, Mysore, for permission to use instruments for this study. We also thank Ms Kavya S, Ms Nirmala J (project officer), Ms Priyanka Mohan (graduate student), and Geeta Kumari Singh (social worker) for valuable input and support during data collection and preparation of the manuscript. We also thank the reviewers for valuable suggestions which helped us improve the text.

\section{References:}

1. Eggermont JJ. The onset and development of auditory function: contributions of evoked potential studies. Journal of Speech Language Pathology and Audiology, 1989; 13: 5-16.

2. Oates PA, Kurtzberg D, Stapells DR. Effects of sensorineural hearing loss on cortical event-related potential and behavioral measures of speech-sound processing. Ear Hear, 2002; 23: 399-415.

3. Hone SW, Norman G, Keogh I, Kelly V. The use of cortical evoked response audiometry in the assessment of noise-induced hearing loss. Otolaryngol Head Neck Surg, 2003; 128: $257-62$.
4. Wunderlich JL, Cone-Wesson BK, Shepherd R. Maturation of the cortical auditory evoked potential in infants and young children. Hear Res, 2006; 212: 185-202.

5. Picton TW, Hillyard SA. Human auditory evoked potentials. II. Effects of attention. Electroencephalogr Clin Neurophysiol, 1974; 36: 191-9.

6. Mendel MI, Hosick EC, Windman TR, Davis H, Hirsh SK, Dinges DF. Audiometric comparison of the middle and late components of the adult auditory evoked potentials awake and asleep. Electroencephalogr Clin Neurophysiol, 1975; 38: $27-33$. 
7. Golding M, Purdy S, Sharma M, Dillon H. The effect of stimulus duration and inter-stimulus interval on cortical responses in infants. Australian and New Zealand Journal of Audiology, 2006; 28: 122-36

8. Novak GP, Kurtzberg D, Kreuzer JA, Vaughan HG. Cortical responses to speech sounds and their formants in normal infants: maturational sequence and spatiotemporal analysis. Electroencephalogr Clin Neurophysiol, 1989; 73: 295-305.

9. Pang EW, Taylor MJ. Tracking the development of the N1 from age 3 to adulthood: an examination of speech and non-speech stimuli. Clin Neurophysiol, 2000; 111: 388-97.

10. Sharma A, Tobey E, Dorman M, Bharadwaj S, Martin K, Gilley $\mathrm{P}$ et al. Central auditory maturation and babbling development in infants with cochlear implants. Arch Otolaryngol Head Neck Surg, 2004; 130: 511-6.

11. Chen BM, Buchwald JS. Midlatency auditory evoked responses: differential effects of sleep in the cat. Electroencephalogr Clin Neurophysiol, 1986; 65: 373-82.

12. Näätänen R, Picton $\mathrm{T}$. The $\mathrm{N} 1$ wave of the human electric and magnetic response to sound: a review and an analysis of the component structure. Psychophysiology, 1987; 24: 375-425.

13. Kraus N, Smith DI, Reed NL, Stein LK, Cartee C. Auditory middle latency responses in children: effects of age and diagnostic category. Electroencephalogr Clin Neurophysiol, 1985; 62(5): 343-51.

14. Kraus N, Mcgee T, Micco A, Sharma A, Carrell T, Nicol T. Mismatch negativity in school-age children to speech stimuli that are just perceptibly different. Electroencephalogr Clin Neurophysiol, 1993; 88(2): 123-30.

15. Carter L, Dillon H, Seymour J, Seeto M, Van Dun B. Cortical auditory-evoked potentials (CAEPs) in adults in response to filtered speech stimuli. J Am Acad Audiol, 2013; 24(9): 807-22.

16. Purdy SC, Sharma M, Munro KJ, Morgan CL. Stimulus level effects on speech-evoked obligatory cortical auditory evoked potentials in infants with normal hearing. Clin Neurophysiol, 2013; 124(3): 474-80.

17. Tremblay KL, Friesen L, Martin BA, Wright R. Test-retest reliability of cortical evoked potentials using naturally produced speech sounds. Ear Hear, 2003; 24(3): 225-32.
18. Kaushlendra K, Jayashree B, Prakrithi U, Pearl D. Effect of click stimuli and speech bursts on cortical processing. Int J Med Eng Inform, 2011; 3: 122-29.

19. Sharma A, Glick H, Campbell J, Biever A. Central auditory development in children with hearing loss: clinical relevance of the P1 CAEP biomarker in hearing-impaired children with multiple disabilities. Hearing Balance Commun, 2013; 11: 22-29.

20. Elangovan S, Stuart A. A cross-linguistic examination of cortical auditory evoked potentials for a categorical voicing contrast. Neurosci Lett, 2011; 490: 140-4.

21. Easwar V, Glista D, Purcell DW, Scollie SD. The effect of stimulus choice on cortical auditory evoked potentials (CAEP): consideration of speech segment positioning within naturally produced speech. Int J Audiol, 2012; 51: 926-31.

22. Shafer VL, Yu YH, Wagner M. Maturation of cortical auditory evoked potentials (CAEPs) to speech recorded from frontocentral and temporal sites: three months to eight years of age. Int J Psychophysiol, 2015; 95: 77-93.

23. Almeqbel A. Speech-evoked cortical auditory responses in children with normal hearing. S Afr J Commun Disord, 2013; 60: 38-43.

24. Gilley PM, Sharma A, Dorman M, Martin K. Developmental changes in refractoriness of the cortical auditory evoked potential. Clin Neurophysiol, 2005; 116: 648-57.

25. Fox AM, Anderson M, Reid C, Smith T, Bishop DV. Maturation of auditory temporal integration and inhibition assessed with event-related potentials (ERPs). BMC Neurosci, 2010; 11: 49.

26. Cone B, Whitaker R. Dynamics of infant cortical auditory evoked potentials (CAEPs) for tone and speech tokens. Int J Pediatr Otorhinolaryngol, 2013; 77: 1162-73.

27. Dun B, Carter L, Dillon H. Sensitivity of cortical auditory evoked potential detection for hearing-impaired infants in response to short speech sounds. Audiol Res, 2012; 13: 65-76.

28. Munro KJ, Purdy SC, Ahmed S, Begum R, Dillon H. Obligatory cortical auditory evoked potential waveform detection and differentiation using a commercially available clinical system: HEARLab ${ }^{\text {тм }}$. Ear Hear, 2011; 32: 782-6.

29. Garinis AC, Cone-Wesson BK. Effects of stimulus level on cortical auditory event-related potentials evoked by speech. J Am Acad Audiol, 2007; 18: 107-16. 